\title{
De Mobiliteitsrichtlijn en implementatie van deze richtlijn voor grensoverschrijdende verrichtingen
}

\author{
Mr. M.H. Baldee en mr. J. Nijland*
}

\begin{abstract}
Dit artikel beschrijft de voorgeschiedenis, totstandkoming en inhoud van Richtlijn (EU) 2019/2121. Auteurs bespreken relevante jurisprudentie en de volgens de Mobiliteitsrichtlijn te volgen procedure om een grensoverschrijdende verrichting tot stand te brengen. Daarnaast bezien zij aan welke instantie het toezicht op de rechtmatigheid van de grensoverschrijdende verrichting kan worden opgedragen.
\end{abstract}

\section{Inleiding}

In december 2019 is de EU-richtlijn betreffende grensoverschrijdende omzettingen, fusies en splitsingen, de zogenoemde Mobiliteitsrichtlijn, gepubliceerd. ${ }^{1}$ Deze richtlijn beoogt vennootschappen een voorspelbaar en geschikt rechtskader te bieden voor verschillende vormen van grensoverschrijdende mobiliteit binnen de Europese Unie (EU), waardoor deze rechtsvormen effectiever gebruik kunnen maken van de vrijheid van vestiging. ${ }^{2}$ De richtlijn is van kracht geworden op 1 januari 2020 en dient uiterlijk 31 januari 2023 in Nederlandse wetgeving te zijn geïmplementeerd. ${ }^{3}$

Over het ontwerp van deze richtlijn is al eerder in dit tijdschrift bericht door onder meer Verbrugh ${ }^{4}$ en Lavreysen. ${ }^{5}$ In onze bijdrage geven we een overzicht van de achtergrond en inhoud van de Mobiliteitsrichtlijn, en van de in de richtlijn vastgelegde procedure om een grensoverschrijdende omzetting, fusie of splitsing tot stand te brengen. Daarnaast bespreken we enkele kwesties die een rol zullen spelen bij de implementatie van de richtlijn.

* Mr. M.H. Baldee is van nov. 2018 t/m dec. 2019 als docent verbonden geweest aan de afdeling Ondernemingsrecht van de Universiteit Leiden. Mr. J. Nijland is als universitair docent verbonden aan de afdeling Ondernemingsrecht van de Universiteit Leiden.

1. Richtlijn (EU) 2019/2121 van het Europees Parlement en de Raad van 27 november 2019 tot wijziging van Richtlijn (EU) 2017/1132 met betrekking tot grensoverschrijdende omzettingen, fusies en splitsingen, PbEU 2019, L 321.

2. Toelichting bij het richtlijnvoorstel van de commissie, $\operatorname{COM}(2018) 241$ (final), p. 1.

3. Art. 3 lid 1 Mobiliteitsrichtlijn.

4. M.A. Verbrugh, Richtlijnvoorstel voor grensoverschrijdende omzettingen, fusies en splitsingen: een (geheel) nieuwe stap in het harmonisatieproces, MvO 2018, afl. 8/9, p. 232-240.

5. M.J.S. Lavreysen, Grensoverschrijdende omzettingen. Gebruiken en hindernissen in de praktijk, MvO 2019, afl. 1/2, p. 55-63.

\section{Vrijheid van vestiging en grensoverschrijdende mobiliteit}

De vrijheid van vestiging is een fundamenteel recht van alle onderdanen van de lidstaten van de EU. Dit recht is vastgelegd in artikel 49 van het Verdrag betreffende de werking van de EU (VWEU). In artikel 54 VWEU wordt bepaald dat dit recht zich uitstrekt tot vennootschappen die in overeenstemming met het recht van een EU-lidstaat zijn opgericht en hun zetel, hoofdbestuur of hoofdvestiging in een EU-lidstaat hebben.

\subsection{Jurisprudentie van het Hof van Justitie van de EU}

Hoe de vrijheid van vestiging voor vennootschappen moet worden uitgelegd, is onderwerp geweest van een lange reeks uitspraken van het Hof van Justitie van de EU (hierna kortweg: het Europese Hof). ${ }^{6}$ Hoewel alle lidstaten het beginsel van de vrijheid van vestiging in theorie onderschreven, bleek dit recht door de lidstaten in de praktijk niettemin beperkt geïnterpreteerd te worden. Dit geschiedde met name vanuit de veronderstelling dat sprake was van misbruik van het recht van vrije vestiging om schuldeisers of andere bij de vennootschap betrokkenen te benadelen. Een veelheid aan nationale juridische en administratieve voorwaarden, beperkingen en verboden beoogde misbruik te voorkomen, maar zorgde eveneens voor een ongewenste belemmering van de mobiliteit van vennootschappen en ondernemingen.

Het Europese Hof heeft bij de beoordeling van dergelijke belemmeringen stelselmatig aangegeven dat de vrijheid van vestiging in beginsel onbeperkt is. Het enkel gebruik maken van een verschil in wetgeving tussen lidstaten en daarbij kiezen voor het rechtsstelsel dat voor de vennootschap het meest gunstig is, is volgens vaste rechtspraak van het Europese Hof op

6. Zie onder meer HvJ EG 9 maart 1999, C-212/97, ECLI:EU:C:1999:126 (Centros), HvJ EG 13 december 2005, C-411/03, ECLI:EU:C: 2005:762 (Sevic), HvJ EG 16 december 2008, C-210/06, ECLI:EU:C: 2008:723 (Cartesio), HvJ EU 12 juli 2012, C-378/10, ECLI:EU:C: 2012:440 (Vale) en HvJ EU 25 oktober 2017, C-106/16, ECLI:EU:C: 2017:804 (Polbud). 


\section{Maandblad}

Ondernemingsrecht

zichzelf onvoldoende om te concluderen dat sprake is van misbruik van de vrijheid van vestiging. ${ }^{7}$

Beperking van het vrije vestigingsrecht is slechts mogelijk indien dit geschiedt (1) zonder onderscheid op basis van de herkomst van de vennootschap uit enige lidstaat en (2) wegens dringende redenen van algemeen belang, zoals de bescherming van aandeelhouders, schuldeisers of werknemers. De beperking moet daarbij (3) geschikt zijn om het beoogde doel te bereiken en (4) niet verder gaan dan voor het bereiken van dat doel noodzakelijk is. ${ }^{8}$

De werkingssfeer van het recht van vestiging strekt zich volgens het Europese Hof uit tot iedere maatregel die de toegang tot een andere lidstaat dan de oorspronkelijke lidstaat van vestiging en de uitoefening van een economische activiteit in die lidstaat mogelijk maakt of vergemakkelijkt, waardoor de vennootschap daadwerkelijk en onder dezelfde voorwaarden kan deelnemen aan het economische leven in die lidstaat. ${ }^{9}$

Omdat er geen richtlijn bestond om op Europees niveau een algemeen kader voor de grensoverschrijdende mobiliteit te bieden, werd de wijze waarop een vennootschap gebruik kon maken van de vrijheid van vestiging bepaald door de nationale wetgeving van de lidstaten die bij een dergelijke activiteit betrokken waren. Door zowel vennootschappen als lidstaten werden in beide richtingen de grenzen opgezocht van de vrijheid van vestiging enerzijds en de beperking van dit recht anderzijds. Het spreekt voor zich dat dit veel rechtsonzekerheid en onduidelijkheid met zich bracht. Gevolg was dat in de praktijk wel gebruik gemaakt werd van de mogelijkheid van grensoverschrijdende omzetting of splitsing, maar niet geheel duidelijk was aan welke voorschriften voldaan zou moeten worden, zodat zekerheidshalve maar alle relevante regels werden gevolgd (voor zover niet tegenstrijdig) of in het geheel van een dergelijke transactie werd afgezien. ${ }^{10}$

\subsection{Richtlijn grensoverschrijdende fusie}

Een keerpunt was de Sevic-uitspraak van het Europese Hof, waarin expliciet werd bepaald dat het tot stand brengen van een juridische fusie een bijzondere vorm is van de uitoefening van de vrijheid van vestiging, die belangrijk is voor een goede werking van de interne markt. ${ }^{11}$ Naar aanleiding van deze uitspraak is de Tiende Richtlijn opgesteld om de juridische fusie van vennootschappen uit verschillende lidstaten te

7. Onder meer HvJ EG 27 september 1988, C-81/87, ECLI:EU:C: 1988:456 (Daily Mail), r.o. 19-21 en HvJ EG 9 maart 1999, C-212/97, ECLI:EU:C:1999:126 (Centros), r.o. 27.

8. HvJ EG 30 november 1995, C-55/94, ECLI:EU:C:1995:411 (Gebhard).

9. HvJ EG 13 december 2005, C-411/03, ECLI:EU:C:2005:762 (Sevic), r.o. 18.

10. G.J.C. Rensen \& K.J. Bakker, Grensoverschrijdende omzetting in de praktijk, WPNR 2016, afl. 7116, p. 593 e.v. en Lavreysen 2019.

11. HvJ EG 13 december 2005, C-411/03, ECLI:EU:C:2005:762 (Sevic). faciliteren. ${ }^{12}$ Deze richtlijn betrof uitsluitend de grensoverschrijdende fusie van kapitaalvennootschappen, en niet de grensoverschrijdende omzetting of splitsing.

Een overweging om de grensoverschrijdende splitsing niet direct in dezelfde richtlijn op te nemen, was het feit dat verschillende lidstaten de Sevic-uitspraak beperkt interpreteerden en daarom uitsluitend een regeling wilden treffen voor de grensoverschrijdende fusie. Daarnaast was relevant dat de bestaande Europese richtlijn betreffende de splitsing van naamloze vennootschappen niet verplichtte tot het opnemen van een wettelijke regeling in nationale wetgeving. ${ }^{13}$ Veel lidstaten kenden mede daardoor de rechtsfiguur van de juridische splitsing nog niet in hun nationale wetgeving. Hierdoor zou het voorschrijven van een Europese regeling voor grensoverschrijdende splitsing prematuur zijn.

De Tiende Richtlijn is in 2008 geïmplementeerd in Nederlandse wetgeving, waarbij de regeling voor de grensoverschrijdende fusie in afdeling $3 \mathrm{~A}$ van titel $2.7 \mathrm{BW}$ is vastgelegd. ${ }^{14}$ De implementatiewet betrof uitsluitend de naamloze vennootschap en de besloten vennootschap met beperkte aansprakelijkheid en zag - evenals de Tiende Richtlijn - uitsluitend op de figuur van de juridische fusie. Bij de totstandkoming van de implementatiewet is weliswaar gesproken over de mogelijkheid om direct een regeling te treffen voor andere rechtsvormen dan kapitaalvennootschappen en voor grensoverschrijdende splitsingen, maar daarvan is afgezien.

Een belangrijke overweging daarvoor was dat een uitbreiding van het bereik van de implementatiewet tot andere rechtsvormen te gecompliceerd zou zijn. Het onderliggende recht van andere in de EU voorkomende rechtsvormen is niet geharmoniseerd, waardoor de nationale voorschriften van die rechtsvormen sterk uiteenlopen. Bovendien is de fusie van andere rechtsvormen niet in Europees verband geregeld. De door de Tiende Richtlijn gehanteerde vooronderstelling van vergelijkbaarheid en gelijkheid van onderliggende voorschriften geldt daardoor niet voor andere rechtspersonen dan kapitaalvennootschappen en andere herstructureringsvormen dan de juridische fusie. Een uitbreiding van de Nederlandse regeling van grensoverschrijdende fusie tot andere rechtsvormen zou daardoor ingewikkeld en dus tijdrovend zijn. Dit alles zou een vertragend effect kunnen hebben op het wetgevingsproces, waardoor tijdige implementatie van de Tiende Richtlijn in

12. Richtlijn 2005/56/EG van het Europees Parlement en de Raad van 26 oktober 2005 inzake grensoverschrijdende fusies van kapitaalvennootschappen, PbEU 2005, L 310. In 2017 is deze richtlijn inhoudelijk ongewijzigd gecodificeerd in Richtlijn (EU) 2017/1132 van het Europees Parlement en de Raad van 14 juni 2017 aangaande bepaalde aspecten van het vennootschapsrecht, PbEU 2017, L 169/46 (de 'Richtlijn Vennootschapsrecht').

13. Zesde Richtlijn 82/891/EEG van de Raad van 17 december 1982 op de grondslag van artikel 54, lid 3, sub g), van het Verdrag betreffende splitsingen van naamloze vennootschappen, in 2017 eveneens gecodificeerd in de Richtlijn Vennootschapsrecht.

14. Art. 2:333b e.v. BW. 
gevaar kon komen. ${ }^{15}$ Een vergelijkbare regeling voor andere rechtsvormen en andere vormen van grensoverschrijdende mobiliteit bleef daardoor zowel op Europees als op nationaal niveau uit.

In 2014 heeft het Ministerie van Veiligheid en Justitie een ambtelijk voorontwerp ter consultatie gepubliceerd voor een regeling voor grensoverschrijdende omzetting van vennootschappen (hierna: Voorontwerp GOO). ${ }^{16}$ Dit voorontwerp leunde sterk op een tekstvoorstel van de Commissie Vennootschapsrecht uit $2012^{17}$ en voorzag in een regeling voor de totstandkoming van een omzetting van EU-vennootschappen in een BV of NV of andersom. Het Voorontwerp GOO heeft na afronding van de consultatie niet geresulteerd in een wetsvoorstel.

\subsection{Ontwikkelingen Europese jurisprudentie over grensoverschrijdende mobiliteit}

Met name op het gebied van de grensoverschrijdende omzetting en grensoverschrijdende splitsing bleef door het gebrek van een heldere regeling onduidelijkheid bestaan over de mogelijkheden, de te volgen procedures en de al dan niet toelaatbare beperkingen. Hierdoor werden er nog altijd veel zaken aan het Europese Hof voorgelegd.

Bij diverse uitspraken gaf het Europese Hof in de rechtsoverwegingen ondubbelzinnig aan dat de vrijheid van vestiging een fundamenteel recht is voor alle vennootschappen uit elke lidstaat, en dat bij gebreke aan Europese harmonisatie en/of nationale regelgeving voor grensoverschrijdende handelingen dit recht niettemin uitgeoefend moet kunnen worden. ${ }^{18}$ Het nationale recht van een lidstaat, zoals dat geldt voor dergelijke handelingen indien die worden verricht binnen de grenzen, bepaalt in die situatie zo veel mogelijk de te volgen procedures voor de totstandkoming van de grensoverschrijdende handeling en de regels ten aanzien van de bescherming van schuldeisers, werknemers en aandeelhouders.

\section{Totstandkoming Richtlijn (EU) 2019/2121}

Er waren al diverse onderzoeken, consultaties en andere pogingen gedaan om te komen tot een heldere regeling van de grensoverschrijdende omzetting of zetelverplaatsing en de

15. Kamerstukken II 2006/07, 30929, nr. 3, p. 2-4 (MvT).

16. Zie www.internetconsultatie.nl/grensoverschrijdende_omzetting/details. Zie over dit consultatievoorstel onder meer E. Schmieman, Contouren voor een wet inzake de grensoverschrijdende omzetting van kapitaalvennootschappen, (Preadvies van de Vereeniging 'Handelsrecht' 2012), Deventer: Kluwer 2012, p. 89-124 en G.C. van Eck \& E.R. Roelofs, Het ambtelijk voorontwerp grensoverschrijdende omzetting van vennootschappen, TvOB 2014, afl. 3, p. 74 e.v. Zie over het tekstvoorstel van de Commissie Vennootschapsrecht E.R. Roelofs \& G.C. van Eck, Een voorstel voor een regeling omtrent grensoverschrijdende omzetting van vennootschappen, WPNR 2013, afl. 6971, p. 296 e.v. (deel I) en WPNR 2013, afl. 6972, p. 313 e.v. (deel II).

17. Brief van de Commissie Vennootschapsrecht aan de Minister van Veiligheid en Justitie, 12 februari 2012, gepubliceerd op 7 september 2012 op www.rijksoverheid.nl.

18. Onder meer HvJ EU 12 juli 2012, C-378/10, ECLI:EU:C:2012:440 (Vale), r.o. 43-47. grensoverschrijdende splitsing, maar dit had nog altijd niet geleid tot een concreet voorstel voor een richtlijn. ${ }^{19}$ Met name op het gebied van werknemersmedezeggenschap bleek het lastig de verschillende politieke meningen te verenigen. Enkele maanden na de uitspraak van het Europese Hof in de zaak Polbud ${ }^{20}$ bleek er (eindelijk) voldoende draagvlak te zijn om te komen tot een voorstel voor een richtlijn om ook de grensoverschrijdende omzetting en grensoverschrijdende splitsing van geharmoniseerde Europese regels te voorzien.

\subsection{Commissievoorstel grensoverschrijdende mobiliteit}

De Europese Commissie heeft in het voorjaar van 2018 haar voorstel voor een richtlijn met betrekking tot de grensoverschrijdende omzetting, de grensoverschrijdende fusie en de grensoverschrijdende splitsing gepubliceerd. ${ }^{21}$ Dit voorstel makkte deel uit van het zogenoemde Company Law Package, dat naast een voorstel voor grensoverschrijdende mobiliteit ook een voorstel inhield voor de digitalisering van onder meer de oprichting van vennootschappen (hierna: Digitaliseringsrichtlijn). ${ }^{22}$

Volgens de toelichting bij het voorstel speelt de vrijheid van vestiging een cruciale rol bij de ontwikkeling van de eengemaakte markt, omdat zij vennootschappen in staat stelt om op een stabiele basis economische activiteiten in andere lidstaten te verrichten. ${ }^{23}$ De richtlijn beoogt vennootschappen een voorspelbaar en geschikt rechtskader te bieden voor grensoverschrijdende omzetting, fusie en splitsing, waardoor zij effectiever gebruik kunnen maken van het vrije vestigingsrecht, waarbij tegelijkertijd passende en evenredige bescherming wordt geboden aan werknemers, schuldeisers en minderheidsaandeelhouders. In de toelichting wordt erkend dat grensoverschrijdende mobiliteit al mogelijk is door de duidelijke interpretatie van de vrijheid van vestiging door het Europese Hof. Maar omdat er nog geen geharmoniseerde regeling bestond, worden de regels voor de te volgen procedure en de te bescher-

19. Zie hierover onder meer Verbrugh 2018, H. Koster, Grensoverschrijdende omzetting van rechtspersonen, Ondernemingsrecht 2018/119 en J. Schmidt, Cross-border mergers, divisions and conversions: Accomplishments and deficits of the Company Law Package, European Company and Financial Law Review (16) 2019, afl. 1/2, p. $225-226$.

20. HvJ EU 25 oktober 2017, C-106/16, ECLI:EU:C:2017:804 (Polbud).

21. Voorstel voor een Richtlijn van het Europees Parlement en de Raad tot wijziging van Richtlijn (EU) 2017/1132 met betrekking tot grensoverschrijdende omzettingen, fusies en splitsingen $\operatorname{COM}(2018) 241$ (final).

22. Richtlijn (EU) $2019 / 1151$ van het Europees Parlement en de Raad van 20 juni 2019 tot wijziging van Richtlijn (EU) 2017/1132 met betrekking tot het gebruik van digitale instrumenten en processen in het kader van het vennootschapsrecht, PbEU 2019, L 186/80. De Digitaliseringsrichtlijn is van kracht geworden op 31 juli 2019 en dient voor 31 augustus 2021 in Nederlandse wetgeving geïmplementeerd te zijn. Zie over de Digitaliseringsrichtlijn onder meer M.A. Verbrugh, Voorstel voor een EU-richtlijn met betrekking tot het gebruik van digitale instrumenten en processen in het kader van het vennootschapsrecht, $\mathrm{MvO} 2018$, afl. $10 / 11$, p. 286-293, J. van der Weele, Digitale oprichting van kapitaalvennootschappen en de rol van de notaris, WPNR 2020, afl. 7266, p. 38 e.v. en K.J. Bakker, De EU-Richtlijn online oprichting van vennootschappen, Ondernemingsrecht 2019/149.

23. Zie p. 1 van de toelichting bij het Commissievoorstel. 


\section{Maandblad}

Ondernemingsrecht

men belangen van minderheidsaandeelhouders, schuldeisers en werknemers of voor de bestrijding van fiscale of andere misbruiken vastgesteld door de lidstaten zelf. Per geval moet worden beoordeeld of dergelijke regels verenigbaar zijn met het EU-recht en met name met de vrijheid van vestiging. De bescherming van de belangen van werknemers, schuldeisers en minderheidsaandeelhouders is door het bestaan van verschillende nationale regels ontoereikend, of de regels zijn overlappend of onderling tegenstrijdig. Dit is onbevredigend voor rechtszekerheid en ongunstig voor vennootschappen, belanghebbenden en lidstaten. ${ }^{24}$

Ten opzichte van het Commissievoorstel zijn in de finale tekst van de Mobiliteitsrichtlijn diverse wijzigingen aangebracht; wij lichten er kort drie uit. ${ }^{25}$

In de eerste plaats is in de richtlijn niet langer voorzien in de mogelijkheid om de benodigde documenten op te stellen in een taal die in het bedrijfsverkeer het gebruikelijkst is. ${ }^{26}$ In bepaalde situaties kan het praktisch zijn om alle stukken op te stellen in het Engels, Frans of Duits, in plaats van in een veelheid van talen die nu nog dwingendrechtelijk kunnen worden voorgeschreven door de lidstaten die betrokken zijn bij een grensoverschrijdende verrichting.

Voorts voorziet de richtlijn niet meer in een mogelijkheid dat de vennootschap zelf een datum vaststelt waarop de grensoverschrijdende fusie of splitsing van kracht wordt - uiteraard voor zover op die datum aan alle voorwaarden voor de totstandkoming zou zijn voldaan. ${ }^{27}$ Volgens de Mobiliteitsrichtlijn komt de grensoverschrijdende verrichting tot stand op de datum die wordt bepaald door de wetgeving van het land van bestemming; in de regel is dat niet een datum die met de betrokken vennootschap(pen) zal worden afgestemd.

In de derde plaats zijn de bepalingen voor de grensoverschrijdende fusie enerzijds en die voor de grensoverschrijdende omzetting en grensoverschrijdende splitsing anderzijds vrijwel gelijkgetrokken. Het Commissievoorstel voorzag op verschillende onderdelen in een aantal bepalingen voor de grensoverschrijdende omzetting en splitsing die niet golden voor de grensoverschrijdende fusie. Een van de meest in het oog springende voorschriften betrof de beoordeling of sprake was van een 'kunstmatige constructie' voor de totstandkoming van een grensoverschrijdende omzetting of splitsing. Om onduidelijke redenen gold deze bepaling niet bij de voorbereiding van een grensoverschrijdende fusie. Dit voorschrift is in de finale versie komen te vervallen.

24. Zie p. 3 van de toelichting bij het Commissievoorstel.

25. Zie over het Commissievoorstel de in noot 19 genoemde bijdragen en daarnaast (met enkele interessante casusvoorbeelden) S. Binard \& L. Schummer, The case for further flexibility in matters of cross-border corporate mobility, European Company Law Journal (16) 2019, afl. 1, p. 31-37.

26. Zie art. 86 quinquies/160 sexies van het Commissievoorstel.

27. Zie art. 122 bis lid $1 / 160$ septies lid 1 van het Commissievoorstel.
Volgens het Commissievoorstel moest worden beoordeeld of sprake was van 'een kunstmatige constructie die bedoeld is om onterechte belastingvoordelen te verkrijgen of de wettelijke rechten van werknemers, schuldeisers of minderheidsaandeelhouders onrechtmatig aan te tasten'. ${ }^{28}$

\subsection{Opzet Mobiliteitsrichtlijn}

De Mobiliteitsrichtlijn brengt wijzigingen aan in de Richtlijn Vennootschapsrecht. ${ }^{29}$ Voor de grensoverschrijdende omzetting wordt aan titel II van de Richtlijn Vennootschapsrecht een nieuw hoofdstuk -1 (!) toegevoegd, bestaande uit de artikelen 86 bis t $/ \mathrm{m} 86$ unvicies. ${ }^{30}$ De grensoverschrijdende splitsing wordt opgenomen in een nieuw hoofdstuk 4 (art. 160 bis t/m 160 duovicies). In hoofdstuk 3, handelend over de grensoverschrijdende fusie, worden eveneens wijzigingen doorgevoerd. Door deze wijzigingen worden enerzijds diverse verbeteringen in de bestaande regeling aangebracht, zoals een verruiming van de mogelijkheid van vereenvoudigde fusie. Anderzijds bewerkstelligen de wijzigingen dat de regeling van de grensoverschrijdende fusie op het gebied van bescherming van aandeelhouders, schuldeisers en werknemers zo veel mogelijk gelijkloopt met die van de omzetting en splitsing.

\subsection{Implementatie Mobiliteitsrichtlijn}

De Mobiliteitsrichtlijn dient uiterlijk op 31 januari 2023 in nationale wetgeving te zijn geïmplementeerd. De bal ligt nu bij de wetgevingsjuristen van het Ministerie van Justitie en Veiligheid. ${ }^{31}$ Bij de implementatie van de richtlijn in Nederlandse wetgeving zal vermoedelijk worden aangesloten bij de huidige regeling voor de grensoverschrijdende fusie (art. 2:333b e.v. BW), die eveneens zal moeten worden aangepast aan de nieuwe tekst van de richtlijn. Of en in hoeverre bij het voorbereiden van de implementatiewet gebruik gemaakt zal worden van de opzet en (delen van) de tekst van het Voorontwerp GOO uit 2014, is nog niet bekend.

28. Zie art. 86 quater lid 3 en 160 quinquies lid 3 van het Commissievoorstel dat lijkt te zijn voorgeschreven naar aanleiding van HvJ EG 12 september 2006, C-196/4, ECLI:EU:C:2006:544 (Cadbury Schweppes), r.o. 51, waar wordt gesproken van een 'volstrekt kunstmatige constructie'. Zie ook J.N. Schutte-Veenstra \& M.A. Verbrugh, De richtlijn betreffende grensoverschrijdende omzetting, fusie en splitsing nader beschouwd, Ondernemingsrecht 2020/40, p. 211-212.

29. Richtlijn (EU) 2017/1132 van het Europees Parlement en de Raad van 14 juni 2017 aangaande bepaalde aspecten van het vennootschapsrecht, PbEU 2017, L 169/46.

30. De nummering van de richtlijn blinkt niet uit in fraaiheid en onderlinge consistentie. Naast de negatieve nummering van dit nieuwe hoofdstuk over grensoverschrijdende omzetting, wijkt de nummering in Latijnse telwoorden in de Nederlandse taalversie (evenals onder meer de Franse, Spaanse en Italiaanse versies) af van onder meer de Engelse, Duitse en Deense taalversies, die gebruik maken van letters (waardoor de artikelen zijn genummerd $86 \mathrm{a} \mathrm{t} / \mathrm{m} 86 \mathrm{t}$ ).

31. Volgens het periodieke overzicht van de Minister van Buitenlandse Zaken betreffende de stand van zaken van de implementatie van richtlijnen in het tweede kwartaal van 2020 ligt de implementatie van de Mobiliteitsrichtlijn achter op schema. Zie bijlage bij de Kamerbrief van 17 juli 2020, p. 8, te raadplegen via www.rijksoverheid.nl/documenten/ kamerstukken/2020/07/17/kamerbrief-stand-van-zaken-implementatieeuropese-richtlijnen-2e-kwartaal-2020. 


\section{Toepassingsbereik Mobiliteitsrichtlijn}

Volgens de Mobiliteitsrichtlijn geldt de faciliteit van de grensoverschrijdende verrichting slechts voor kapitaalvennootschappen; in Nederland uitsluitend voor de naamloze vennootschap en de besloten vennootschap met beperkte aansprakelijkheid. ${ }^{32}$

Voor andere rechtspersonen, die niet kwalificeren als vennootschap in de zin van de Mobiliteitsrichtlijn, maar wel als vennootschap als bedoeld in artikel 54 VWEU, is nog altijd geen regelgevend kader beschikbaar. Dit leidt tot voortduring van rechtsonzekerheid en tot beperking van de vrijheid van vestiging voor rechtspersonen van dit type, die volgens vaste rechtspraak van het Europese Hof immers ook zonder concrete regelgeving bestaat.

Bij de Nederlandse implementatiewet zou een regeling kunnen worden getroffen om ook voor andere rechtspersonen grensoverschrijdende mobiliteit mogelijk te maken. Gelet op de in paragraaf 2.1 besproken overwegingen bij de implementatie van de Tiende Richtlijn in Nederlandse wetgeving, ligt het niet in de lijn der verwachting dat de implementatiewet voor de Mobiliteitsrichtlijn zich ditmaal wel zal uitstrekken tot andere rechtspersonen.

Een andere beperking die de richtlijn stelt, is dat vennootschappen die in vereffening zijn, waarbij is begonnen met de verdeling van activa, niet mogen deelnemen aan een grensoverschrijdende verrichting. Lidstaten kunnen er daarnaast onder meer voor kiezen de richtlijn niet toe te passen op vennootschappen die in een insolventieprocedure of soortgelijke procedure verwikkeld zijn. ${ }^{33}$

Uitgangspunt van de Mobiliteitsrichtlijn is dat de betrokkenen bij een vennootschap die in financiële moeilijkheden verkeert, beschermd moeten worden tegen misbruik van grensoverschrijdende mobiliteit. Een grensoverschrijdende verrichting kan echter juist ook een nuttige rol spelen bij de reorganisatie of herstructurering van een groep vennootschappen die financiële problemen ondervindt, om aldus aan een goed renderend gedeelte van de groep redding te bieden. Het redden van een vennootschap kan gunstig zijn voor alle bij de vennootschap betrokkenen, waaronder schuldeisers die anders onbetaald achterblijven en werknemers die anders hun baan zouden verliezen.

Het is spijtig dat deze mogelijkheid door lidstaten zonder meer kan worden uitgesloten, omdat de benadeling van aandeelhouders, schuldeisers en/of werknemers ook op andere wijze zou kunnen worden voorkomen, door duidelijke voorwaarden en regels voor deze specifieke situatie te stellen om misbruik te voorkomen.

32. Zie Bijlage II van de Richtlijn Vennootschapsrecht.

33. Art. 86 bis/118 en $120 / 160$ bis.

\section{Procedure grensoverschrijdende verrichting}

De drie varianten van grensoverschrijdende mobiliteit (omzetting, fusie en splitsing) worden in de richtlijn gezamenlijk aangeduid als 'grensoverschrijdende verrichtingen', een term waarbij wij in dit artikel aansluiten. ${ }^{34}$ In de basis is de manier waarop een grensoverschrijdende verrichting tot stand komt voor de drie varianten gelijk. Hieronder beschrijven we op hoofdlijnen de belangrijkste stappen in de procedure voor het tot stand komen van een grensoverschrijdende omzetting, fusie of splitsing, zonder in te gaan op de (overigens interessante) bijzonderheden van de afzonderlijke verrichtingen. Een vennootschap die betrokken is bij een grensoverschrijdende verrichting moet de voorgeschreven stappen en formaliteiten doorlopen in de lidstaat waar zij gevestigd of opgericht is. ${ }^{35}$ Vervolgens wordt in de lidstaat waarheen de grensoverschrijdende verrichting zich beweegt, beoordeeld of ook daar aan de voorgeschreven formaliteiten is voldaan.

\subsection{Voorstel van het bestuur tot omzetting, fusie of splitsing}

In de eerste plaats wordt door het bestuur van de betrokken vennootschap(pen) een voorstel opgesteld waarin wordt aangegeven wat de intentie van de voorgenomen verrichting is en wat de verwachte gevolgen daarvan zijn. ${ }^{36}$ Het voorstel bevat onder meer de gegevens van de betrokken vennootschap(pen), de huidige en toekomstige statuten en een indicatief tijdschema voor de totstandkoming van de verrichting. Voorts dient te worden aangegeven welke waarborgen aan schuldeisers worden geboden, en bij fusie en splitsing wat de ruilverhouding van de aandelen is en welke vergoedingen aan deelnemers (aandeelhouders) beschikbaar worden gesteld. Tevens wordt vermeld wat de verwachte gevolgen zijn voor de werkgelegenheid en hoe werknemers worden betrokken bij de vaststelling van hun medezeggenschapsrechten.

\subsection{Verslag voor aandeelhouders en voor werknemers}

Zowel voor de aandeelhouders als voor de werknemers stelt het bestuur een verslag op waarin de wettelijke en economische aspecten van de grensoverschrijdende verrichting worden toegelicht, evenals de gevolgen voor de werknemers en de toekomstige bedrijfsactiviteiten van de vennootschap. ${ }^{37}$ De verslagen mogen naar keuze van de vennootschap apart worden opgesteld, of tot één document worden gecombineerd.

In (het deel van) het verslag bestemd voor de aandeelhouders wordt in ieder geval informatie gegeven over de gevolgen van de grensoverschrijdende verrichting voor de aandeelhouders en de financiële aspecten. Aandeelhouders die tegen het voor-

\footnotetext{
34. De verwijzingen naar artikelnummers in dit onderdeel zijn verwijzingen naar de door de Mobiliteitsrichtlijn gewijzigde Richtlijn Vennootschapsrecht, tenzij anders is aangegeven. In de noten bij dit onderdeel staan veelal drie artikelnummers vermeld, respectievelijk betreffende de grensoverschrijdende omzetting, de grensoverschrijdende fusie en de grensoverschrijdende splitsing.

35. Art. 86 quater $/ 122 / 160$ quater.

36. Lid 1 van art. 86 quinquies/124/160 quinquies.

37. Art. 86 sexies/124/160 sexies.
} 
stel tot de grensoverschrijdende verrichting hebben gestemd, krijgen het recht uit de vennootschap te treden tegen een adequate geldelijke vergoeding van de waarde van hun aandelen. ${ }^{38}$ Deze regeling kan bij implementatie ook worden uitgebreid tot andere aandeelhouders, bijvoorbeeld de houders van aandelen waaraan geen stemrecht verbonden is. ${ }^{39}$

In (het deel van) het verslag bestemd voor de werknemers wordt in ieder geval informatie gegeven over de gevolgen van de grensoverschrijdende verrichting voor de arbeidsrelaties en arbeidsvoorwaarden betreffende de vennootschap en haar dochterondernemingen. ${ }^{40}$

In bepaalde gevallen behoeft in het geheel geen verslag te worden opgesteld. Het verslag voor de aandeelhouders is niet vereist indien alle aandeelhouders ermee hebben ingestemd van dat vereiste af te zien. Het werknemersverslag is niet vereist indien alle werknemers van de betrokken vennootschap deel uitmaken van het bestuur van die vennootschap of een dochteronderneming. ${ }^{41} \mathrm{Bij}$ implementatie kan daarnaast worden bepaald dat de verslagen niet vereist zijn indien sprake is van een eenpersoonsvennootschap.

\subsection{Deskundigenverslag}

Een onafhankelijke deskundige onderzoekt vervolgens het voorstel, de eventuele uittreedvergoeding en de ruilverhouding. De vennootschap moet de deskundige hiertoe van alle benodigde informatie voorzien. De deskundige stelt voor de aandeelhouders een verslag op waaruit moet blijken dat de gebruikte waarderingsmethode passend en de uittreedvergoeding adequaat is. ${ }^{42}$

Dit onderzoek door en het verslag van de deskundige zijn niet vereist indien alle aandeelhouders van de betrokken vennootschap dat zijn overeengekomen. Bij implementatie kunnen de lidstaten ervoor kiezen te bepalen dat de voorschriften omtrent het deskundigenverslag niet zullen gelden voor de eenpersoonsvennootschap.

In nationale wetgeving moeten regels worden opgenomen betreffende de onafhankelijkheid en onpartijdigheid van de deskundige, en ten aanzien van zijn civielrechtelijke aansprakelijkheid. ${ }^{43}$

38. Art. 86 decies/126 bis/160 decies. Zie voor een meer uitgebreide beschrijving van de regeling voor uittreding van aandeelhouders P.P. de Vries, Het uittredingsrecht voor aandeelhouders bij grensoverschrijdende omzetting, fusie en splitsing onder de Mobiliteitsrichtlijn, Ondernemingsrecht 2020/41, p. 219 e.v., en over het uittreedrecht van aandeelhouders van de verkrijgende vennootschap M.A. Verbrugh, Naar een beter Europees ondernemingsrecht, Ondernemingsrecht 2020/20, p. 104.

39. E.R. Roelofs \& G.C. van Eck, Inwerkingtreding van de 'Mobiliteitsrichtlijn' en grensoverschrijdende omzetting, JBN 2020/11.

40. Zie voor een meer uitgebreide beschrijving van de regeling van werknemersmedezeggenschap Schutte-Veenstra \& Verbrugh 2020, p. 215 e.v.

41. Zie lid 4 respectievelijk lid 8 van art. 86 sexies/124/160 sexies.

42. Art. 86 septies/125/160 septies.

43. Art. 86 vicies $/ 133$ bis $/ 160$ unvicies.

\subsection{Bescherming van schuldeisers}

Aan schuldeisers die een vordering op de vennootschap hebben die is ontstaan voordat het voorstel voor de grensoverschrijdende verrichting openbaar is gemaakt, maar die nog niet opeisbaar is, dient nationale wetgeving passende bescherming te bieden. ${ }^{44}$

Om de positie van schuldeisers verdergaand te beschermen kan bij implementatie worden voorgeschreven dat het bestuur een verklaring dient te verstrekken waaruit moet blijken dat het bestuur op basis van de beschikbare informatie niet verwacht dat de vennootschap door het van kracht worden van de grensoverschrijdende verrichting niet aan haar verplichtingen zal kunnen voldoen wanneer deze opeisbaar worden. Aldus wordt beoogd te voorkomen dat bestuurders al te lichtvaardig gebruik zullen maken van een grensoverschrijdende verrichting.

Schuldeisers kunnen desgewenst bij de rechter verzoeken dat aanvullende waarborgen worden verstrekt indien de voldoening van hun vordering aantoonbaar in het gedrang zal komen door de grensoverschrijdende verrichting, en zij geen genoegen wensen te nemen met de in het voorstel genoemde waarborgen. ${ }^{45}$

\subsection{Openbaarmaking voorstel}

De volgende stap bestaat erin dat het voorstel en (indien voorgeschreven) de bestuursverklaring over de financiële positie van de vennootschap openbaar worden gemaakt. ${ }^{46}$ Daarbij doet de vennootschap een kennisgeving aan aandeelhouders, schuldeisers en (vertegenwoordigers van) werknemers dat zij opmerkingen ten aanzien van het voorstel bij de vennootschap kunnen indienen. Bij implementatie in nationale wetgeving kan wettelijk worden vastgelegd dat ook het deskundigenverslag openbaar moet worden gemaakt, voor zover de daarin opgenomen informatie niet vertrouwelijk is.

Het voorstel wordt in beginsel openbaar gemaakt via het handelsregister. De openbaarmaking geschiedt in het register van de lidstaat waarin de betrokken vennootschap ten tijde van het voorstel (nog) gevestigd is; door een systeem van gekoppelde registers is deze informatie ook in andere lidstaten beschikbaar voor het publiek.

Bij implementatie kan worden bepaald dat een vennootschap de openbaarmaking van het voorstel en de kennisgeving (in plaats van via het register) gratis laat plaatsvinden via haar website. In het register dient dan alsnog opgave te worden gedaan van het voornemen tot de grensoverschrijdende verrichting, onder vermelding van gegevens van de website en de registers waar alle relevante informatie te vinden is, en welke

44. Art. 86 undecies/ 126 ter/160 undecies.

45. Zie over bescherming van crediteuren Schutte-Veenstra \& Verbrugh 2020, p. 213-215.

46. Art. 86 octies/123/160 octies. 
regelingen zijn getroffen voor de uitoefening van de rechten van aandeelhouders, schuldeisers en werknemers.

Bij implementatie kunnen lidstaten voorschrijven dat naast de openbaarmaking via het openbaar register of via de website van de vennootschap, eveneens een aankondiging in het nationale publicatieblad dient plaats te vinden.

De gehele procedure van openbaarmaking moet online kunnen geschieden, zonder dat de aangevers in persoon bij enige instantie moeten verschijnen. Dit is geheel in lijn met de Digitaliseringsrichtlijn. ${ }^{47}$

\subsection{Goedkeuring algemene vergadering}

De algemene vergadering van de vennootschap dient door het nemen van een besluit de voorgenomen grensoverschrijdende verrichting goed te keuren. ${ }^{48}$

De algemene vergadering waarin dit onderwerp besproken zal worden, kan eerst worden gehouden na verloop van ten minste zes weken nadat het voorstel en de verslagen aan de aandeelhouders en werknemers ter beschikking zijn gesteld. ${ }^{49}$ Het deskundigenverslag moet ten minste één maand voor de algemene vergadering voor de aandeelhouders beschikbaar zijn gemaakt $\mathrm{t}^{50}$ en de openbaarmaking moet ook ten minste één maand voor de algemene vergadering hebben plaatsgevonden. ${ }^{51}$ Ten slotte moeten de aandeelhouders in de gelegenheid zijn geweest om kennis te nemen van de mogelijk ingediende opmerkingen van aandeelhouders, schuldeisers en werknemers ten aanzien van het voorstel. Deze opmerkingen moeten uiterlijk vijf werkdagen voor de datum van de algemene vergadering door de vennootschap zijn ontvangen.

Voor het besluit tot goedkeuring van een grensoverschrijdende omzetting of splitsing is een versterkte meerderheid voorgeschreven van twee derde tot $90 \%$ van de uitgebrachte stemmen of van het geplaatste kapitaal, te bepalen bij de implementatie van de richtlijn in nationale wetgeving. De bij implementatie te bepalen stemmingsdrempel mag in ieder geval niet hoger zijn dan die in nationale wetgeving reeds is voorgeschreven voor het nemen van een besluit tot grensoverschrijdende fusie. ${ }^{52}$

47. Zie noot 19 .

48. Art. 86 nonies $/ 126 / 160$ nonies.

49. Lid 6 van art. 86 sexies/ $124 / 160$ sexies.

50. Lid 1 van art. 86 septies/125/160 septies.

51. Lid 6 van art. 86 octies/123/160 octies.

52. Zie art. 2:330 BW, dat een meerderheid van ten minste twee derde van de uitgebrachte stemmen voorschrijft indien minder dan de helft van het geplaatste kapitaal in de vergadering vertegenwoordigd is. Indien meer dan de helft van het geplaatste kapitaal vertegenwoordigd is in de vergadering, geldt een volstrekte meerderheid. Voor een grensoverschrijdende fusie wordt geen andere meerderheid vereist dan voor een fusie met uitsluitend Nederlandse rechtspersonen.

\subsection{Aan de grensoverschrijdende verrichting voorafgaand attest}

Door elk van de lidstaten wordt een rechterlijke, notariële of andere instantie aangewezen die toezicht houdt op enerzijds de rechtmatigheid van de verrichting en anderzijds de naleving van de procedures en voorgeschreven formaliteiten voor de totstandkoming van de grensoverschrijdende verrichting in de lidstaat van vertrek (de 'outbound instantie'). ${ }^{53}$ De bevoegde instantie onderzoekt eveneens of de voorschriften omtrent werknemersmedezeggenschap ${ }^{54}$ correct zijn nageleefd.

Zodra aan alle voorschriften is voldaan en er geen twijfels bestaan aangaande de rechtmatigheid van de voorgenomen verrichting, verklaart de outbound instantie in een attest dat aan alle relevante voorwaarden is voldaan en dat alle procedures en formaliteiten in de lidstaat van vertrek correct zijn vervuld.

Ten behoeve van de beoordeling door de bevoegde instantie verstrekt de vennootschap alle relevante gegevens, zoals onder meer het voorstel, het verslag voor de aandeelhouders en de werknemers, het deskundigenverslag, de ingediende opmerkingen betreffende het voorstel en informatie over de goedkeuring van de verrichting door de algemene vergadering. Bij implementatie kan worden bepaald dat daarnaast aanvullende informatie moet worden verstrekt.

De gehele procedure voor de beoordeling en afgifte van de verklaring door de outbound instantie moet volledig online kunnen worden verricht, zonder dat de aanvrager persoonlijk hoeft te verschijnen. De procedure duurt in beginsel niet langer dan drie maanden, te rekenen vanaf de dag dat de benodigde gegevens door de instantie zijn ontvangen.

Indien niet aan alle formaliteiten en verplichtingen is voldaan, kan het attest niet worden verstrekt en kan de bevoegde instantie de vennootschap in de gelegenheid stellen om alsnog aan de gestelde voorwaarden of formaliteiten te voldoen. In dat geval wordt de termijn voor afgifte van het attest verlengd.

De outbound instantie weigert het attest te verstrekken indien overeenkomstig het nationale recht 'wordt vastgesteld dat de grensoverschrijdende verrichting is opgezet voor frauduleuze of onrechtmatige doeleinden die leiden tot of gericht zijn op ontduiking van Unie- of nationaal recht, of voor criminele doeleinden'. 55

Indien de bevoegde instantie ernstige twijfels heeft bij haar beoordeling, die erop wijzen dat de grensoverschrijdende verrichting mogelijk is opgezet voor onrechtmatige of frauduleuze doeleinden, wordt een nader onderzoek gedaan. De procedure voor de beoordeling voor de afgifte van het attest wordt dan met maximaal drie maanden verlengd. Voor de nadere

53. Art. 86 quaterdecies $/ 127 / 160$ quaterdecies.

54. Zie art. 86 terdecies $/ 133 / 160$ terdecies en noot 40 .

55. Lid 8 van art. 86 quaterdecies/127/160 quaterdecies. 


\section{Maandblad \\ Ondernemingsrecht}

beoordeling wordt bij implementatie van de richtlijn in het nationale recht een procedure vastgesteld. $\mathrm{Bij}$ de nadere beoordeling kan de bevoegde instantie informatie en documenten opvragen die bij andere instanties beschikbaar zijn, en een onafhankelijke deskundige inschakelen.

We zullen in paragraaf 6 nader ingaan op deze rechtmatigheidstoets.

\subsection{Voortzetting procedure in andere lidstaat}

Het door de outbound instantie afgegeven attest wordt gedeeld via een systeem van gekoppelde registers en is op die manier beschikbaar voor de bevoegde instantie van de lidstaat van bestemming (de 'inbound instantie'). ${ }^{56}$ Ook dit is een rechterlijke, notariële of andere instantie die bevoegd is toezicht te houden op de rechtmatigheid van de verrichting en op de naleving van de voorwaarden in de lidstaat van bestemming.

De inbound instantie onderzoekt of aan alle vereisten en formaliteiten is voldaan, met name ook op het gebied van werknemersmedezeggenschap en besluitvorming door de algemene vergadering. Het attest dat door de outbound instantie is verstrekt, geldt voor de inbound instantie als afdoende bewijs dat aan alle voorwaarden in de lidstaat van vertrek is voldaan.

$\mathrm{Na}$ het afronden van het eigen onderzoek door de inbound instantie en ontvangst van het attest van de outbound instantie kan de grensoverschrijdende verrichting door de inbound instantie worden goedgekeurd.

\subsection{Afronding grensoverschrijdende verrichting}

De grensoverschrijdende verrichting wordt vervolgens van kracht op de datum die volgt uit de nationale wetgeving van de lidstaat van bestemming. ${ }^{57}$ Ten slotte dient de grensoverschrijdende verrichting te worden ingeschreven in de registers. $^{58}$

\section{Toezicht op de rechtmatigheid - door de notaris?}

\subsection{Expertise ondernemingsrecht}

Bij implementatie dient te worden bepaald welke instantie in Nederland bevoegd zal zijn om te beoordelen of is voldaan aan alle voorschriften en of de grensoverschrijdende verrichting al dan niet frauduleuze of onrechtmatige doeleinden heeft. Het is nog geen uitgemaakte zaak hoe en door wie deze rechtmatigheidstoets moet worden uitgevoerd.

Voor de bestaande Nederlandse regeling voor de grensoverschrijdende fusie is de notaris de bevoegde instantie om het prefusieattest te verstrekken. ${ }^{59}$ De notaris is bij uitstek deskundig op het gebied van diverse vennootschapsrechtelijke

56. Art. 86 quindecies $/ 127$ bis/ 160 quindecies.

57. Art. 86 octodecies/129/160 octodecies.

58. Art. 86 septdecies/130/160 septdecies.

59. Art. 2:333i lid $3 \mathrm{BW}$. handelingen, en is exclusief bevoegd tot het verlijden van akten waarbij rechtspersonen ontstaan of van karakter wijzigen, zoals omzetting, fusie of splitsing. Er is geen betere instantie dan de notaris denkbaar voor enerzijds de analyse en begeleiding van het proces van de grensoverschrijdende verrichting vanuit ondernemingsrechtelijk perspectief en anderzijds de beoordeling van de correcte uitvoering en naleving van de voorwaarden en formaliteiten. Echter, de beoordeling van de rechtmatigheid van de grensoverschrijdende verrichting zoals wordt voorgeschreven door de Mobiliteitsrichtlijn, is een andere kwestie.

\subsection{Taak notaris}

Een Nederlandse notaris is naast ondernemer ook openbaar ambtenaar en is in dat kader ook nu al gewend gedegen onderzoek te doen naar de intenties en achtergrond van de betrokkenen bij voorgenomen transacties. ${ }^{60}$ De notaris is belast met een publieke taak en heeft in het rechtsverkeer een belangrijke functie als persoonlijk en/of zakelijk dienstverlener met vertrouwensfunctie. Hij heeft vanouds een rol in het onafhankelijk en onpartijdig constateren van rechtsfeiten en het vaststellen van de naleving van formaliteiten, en zijn werkzaamheden zijn gericht op het bevorderen van de rechtszekerheid en de bescherming van het rechtsverkeer, waarbij rekenschap moet worden gegeven aan de belangen van derden en het openbaar belang.

De notaris heeft daarbij een 'poortwachtersfunctie', gericht op het voorkomen van criminele of frauduleuze gedragingen. De notaris is niet lijdelijk, maar moet actief doorvragen en onderzoek doen naar de achtergrond en effecten van een transactie. $\mathrm{Bij}$ een redelijke overtuiging of zelfs een redelijk vermoeden dat sprake is van misbruik of fraude, moet de notaris zijn diensten weigeren.

De notaris is op grond van de Wet op het notarisambt (Wna) verplicht de hem bij of krachtens de wet opgedragen - of door een cliënt verlangde - werkzaamheden te verrichten. Hij moet zijn notariële diensten verlenen op de gebieden waar hij een domeinmonopolie heeft, omdat zijn tussenkomst wettelijk is voorgeschreven. Daarbij is te denken aan het opstellen van een testament, een hypotheekakte, een akte van oprichting van een rechtspersoon of een akte van levering van aandelen. ${ }^{61}$ Deze verplichte dienstverlening wordt aangeduid als de ministerieplicht. ${ }^{62}$ De notaris is echter eveneens verplicht zijn dienst te weigeren als naar zijn redelijke overtuiging of vermoeden de handeling die van hem wordt verlangd, leidt tot strijd met het recht of de openbare orde, of die handeling kennelijk een ongeoorloofd doel of gevolg heeft. ${ }^{63}$ Ook deze

60. Zie onder meer de verplichtingen van de notaris vastgelegd in de Wet ter voorkoming van witwassen en financieren van terrorisme ( $\mathrm{Wwft}$ ) en de Wna.

61. Art. $21 \mathrm{Wna}$.

62. Zie over dit onderwerp T.J. Mellema-Kranenburg, De ministerieplicht van de notaris, AA 2020, afl. 1, p. 100 e.v.

63. Lid 2 van genoemd artikel. 
norm gaat uit van redelijke overtuiging of vermoeden, gericht op redelijkerwijs van de notaris te verwachten onderzoek.

Indien de afgifte van het attest als bedoeld in de Mobiliteitsrichtlijn aan de notaris zou worden opgedragen, gelden voor deze handeling ook de ministerieplicht en de plicht tot weigering. Daarmee zou de notaris in zijn rol als poortwachter ook hier terecht een belangrijke rol spelen.

\subsection{Notaris als opsporingsdienst?}

Het onderzoek dat op grond van de Mobiliteitsrichtlijn verlangd wordt van de bevoegde instantie die het attest moet afgeven, is aanmerkelijk dieper en verdergaand dan het onderzoek dat nu van de notaris wordt verlangd onder de huidige wettelijke regeling voor de grensoverschrijdende fusie. De rechtmatigheidstoets is weliswaar minder veelomvattend dan de beoordeling of sprake is van een 'kunstmatige constructie', zoals in het Commissievoorstel was opgenomen, maar blijft complex en vergt een vergaande mate van kennis van zaken. ${ }^{64}$ Bij ernstige twijfel over de redenen voor de grensoverschrijdende verrichting moet de bevoegde instantie nader onderzoek doen, waarbij ook informatie en documenten van andere instanties kunnen worden opgevraagd. Welke informatie of documenten dat kunnen zijn, en welke instanties kunnen worden bevraagd, is nog niet duidelijk, maar het is prima facie de vraag of deze ontwikkeling wenselijk is. De van de bevoegde instantie verlangde rechtmatigheidstoets, zoals beschreven in de Mobiliteitsrichtlijn, ligt naar onze mening voor wat betreft de elementen fraude en criminaliteit eerder op het pad van een opsporingsdienst dan van de notaris.

Een belangrijke overweging is in de eerste plaats dat de notaris niet in dezelfde mate als een reguliere overheidsopsporingsdienst over de middelen en systemen beschikt om fraude op te sporen. De notaris zou een aanzienlijke uitbreiding van bevoegdheden en instrumenten nodig hebben om adequaat toezicht te kunnen uitoefenen op de rechtmatigheid en al dan niet frauduleuze of criminele intenties bij het tot stand brengen van de grensoverschrijdende verrichting. De verschuiving van opsporingsbevoegdheden van overheid naar notaris is niet noodzakelijkerwijs wenselijk. Dit is eveneens opgemerkt in het kader van de fraudepreventie bij het digitaliseren van het oprichtingsproces ingevolge de Digitaliseringsrichtlijn. ${ }^{65}$

Daar komt bij dat de notaris een zelfstandig opererende ondernemer is, die zijn eigen inhoudelijke en commerciële afwegingen maakt en beslissingen neemt. Zelfs indien de notaris toegang krijgt tot diverse registers, dan zal de uitvoering van opsporingsactiviteiten niet door alle notarissen op dezelfde wijze plaatsvinden. Het is de vraag hoe consistent het uitgevoerde toezicht op de rechtmatigheid zal zijn, aangezien de notaris niet in overheidsdienst is en daarom geen concrete beleidsaanwijzingen of instructies van een leidinggevend

64. Zie ook Verbrugh 2020, p. 104, noot 45.

65. Van der Weele 2020, p. 44. orgaan behoeft op te volgen. De ene notaris zal binnen de aangegeven marges ongetwijfeld prudenter zijn dan de andere.

Het feit dat de notaris geen overheidsdienst is, betekent ook dat de gangbare waarborgen voor overheidsoptreden niet gelden. Er moet vanuit privacyoverwegingen zorgvuldig worden vastgesteld tot welke informatie de notaris wel en geen toegang zal hebben. Dan is het vervolgens de vraag in hoeverre de notaris zich een volledig beeld kan vormen van een mogelijk frauduleuze of criminele opzet, als hij geen volledige toegang tot alle informatie heeft.

In het rapport 'Oprichten zonder omwegen' komen Timmerman en Stokkermans eveneens tot de conclusie dat het afgeven van een verklaring over de fraudecheck beter bij een overheidsinstantie zou passen. ${ }^{66}$

\subsection{Samenwerking met Justis}

Sinds het afschaffen van de verklaring van geen bezwaar voor de oprichting van een vennootschap wordt een doorlopend toezicht op rechtspersonen ingevolge de Wet controle op rechtspersonen uitgevoerd door Justis, de screeningsautoriteit van het Ministerie van Justitie en Veiligheid. ${ }^{67}$ Justis heeft toegang tot allerlei gegevens die bij de overheid bekend zijn, waaronder de registers van de Belastingdienst en de politie. Zij voert aan de hand van alle beschikbare informatie automatische en expertanalyses uit naar de bij een vennootschap betrokken personen en mogelijke stromanconstructies. ${ }^{68}$ Justis heeft enerzijds de nodige deskundigheid, bevoegdheden en systemen om dit toezicht effectief te kunnen uitoefenen, en wordt anderzijds als overheidsinstantie democratisch gecontroleerd. Dit lijkt ons daarom de aangewezen instantie om aan de notaris die de transactie juridisch inhoudelijk begeleidt een verklaring te verstrekken betreffende de uitkomsten van het door Justis uitgevoerde onderzoek naar fraude of criminele achtergronden.

Een terugkeer naar het systeem van de verklaring van geen bezwaar, zoals dat gold voor de oprichting van een vennootschap, lijkt ons voor de praktijk echter onwenselijk, gelet op het mogelijk vertragend effect daarvan. In het eerdergenoemde

66. L. Timmerman \& Chr.M. Stokkermans, Oprichten zonder omwegen. Digitalisering en fraudebestrijding als game changers voor de oprichtingsprocedures van vennootschappen (onderzoeksrapport in opdracht van het Ministerie van Economische Zaken en Klimaat), 22 mei 2020, p. 71.

67. Wet van 7 juli 2010 tot wijziging van onder meer Boek 2 van het Burgerlijk Wetboek en de Wet documentatie vennootschappen in verband met het vervallen van de verklaring van geen bezwaar en het verbeteren en uitbreiden van de controle op rechtspersonen met het oog op de voorkoming en bestrijding van misbruik van rechtspersonen (Stb. 2010, 280) en Besluit van 8 april 2011 tot wijziging van het Besluit documentatie vennootschappen en enige andere besluiten in verband met het vervallen van de verklaring van geen bezwaar en het verbeteren en uitbreiden van de controle op rechtspersonen met het oog op de voorkoming en bestrijding van misbruik van rechtspersonen (Stb. 2011, 180), in werking getreden op 1 juli 2011.

68. Zie de factsheet 'Wet controle op rechtspersonen', pdf-versie d.d. 15 juli 2020, te raadplegen via www.justis.nl/producten/toezicht-oprechtspersonen/. 


\section{Maandblad}

Voorontwerp GOO werd aan het Ministerie van Veiligheid en Justitie de mogelijkheid gegeven om verzet aan te tekenen tegen een voorgenomen grensoverschrijdende omzetting. ${ }^{69}$ Wellicht kan bij de thans in te richten procedure worden gedacht aan de gang van zaken die aansluit bij de bestaande praktijk voor de afgifte van een akte non-verzet, die door de rechtbank wordt verstrekt bij een voorgenomen juridische fusie of splitsing, waaruit moet blijken dat geen schuldeisers in verzet zijn gekomen tegen een voorstel tot fusie. ${ }^{70}$ Alleen indien zich bijzonderheden voordoen, wordt dat aangegeven in de verklaring.

Door de publicatie in het handelsregister krijgt Justis een signalering van de voorgenomen grensoverschrijdende verrichting. Vervolgens kan Justis in de daaropvolgende maand haar analyse uitvoeren naar mogelijke frauduleuze of criminele intenties, en naar de antecedenten van de bij de vennootschap betrokken personen. $\mathrm{Na}$ afloop van de maand vraagt de notaris bij het handelsregister of bij Justis een verklaring op of er wel of geen bezwaren zijn, en of aanvullend onderzoek zal worden uitgevoerd, wanneer er ernstige twijfels zijn gerezen. ${ }^{71}$ In dat geval heeft Justis nog drie maanden de tijd voor een verdergaand onderzoek.

In deze opzet kan de notaris bij wie het attest wordt aangevraagd, zich focussen op zijn eigenlijke, juridische, taak (met poortwachtersfunctie) en kan hij voor de beoordeling van frauduleuze of criminele intenties vertrouwen op de door Justis verstrekte verklaring. Dat lijkt ons een juiste en evenwichtige benadering van het uit te voeren rechtmatigheidstoezicht.

\section{Conclusie}

Het is een grote vooruitgang voor de Europese bewegingsvrijheid van kapitaalvennootschappen dat de Mobiliteitsrichtlijn is vastgesteld. De lidstaten hebben op verschillende onderwerpen nog wat bewegingsvrijheid bij de implementatie van de richtlijn. In de basis zullen de voorbereiding en totstandkoming van een grensoverschrijdende verrichting aanzienlijk eenvoudiger en overzichtelijker zijn dan voorheen het geval was. Daarnaast is het toe te juichen dat een duidelijk en geharmoniseerd kader aan regels is vastgesteld om de belangen van de bij de vennootschap betrokkenen te beschermen. Ook dit draagt bij aan de rechtszekerheid.

Wij zien graag uit naar het Nederlandse voorstel voor de implementatiewet. 